\title{
Localization of Mandibular Foramen and Clinical Implications
}

\author{
Localización del Foramen Mandibular e Implicancias Clínicas
}

\author{
*Jussara Peixoto Ennes \& ** Rafael Monteiro de Medeiros
}

ENNES, J. P. \& MEDEIROS, R. M. Localization of mandibular foramen and clinical implications. Int. J. Morphol., 27(4):1305-1311, 2009.

SUMMARY: The mandibular foramen constitutes an anatomical repair to anesthetics and surgical procedures. Its localization is surrounded by difficulties and a source of disagreement. The goal of this investigation was to identify the MF location in human mandibles presenting variable number of teeth and in edentulous ones. And from the data given by the literature, short anesthetic needles were analyzed as to their suitability to block the inferior alveolar nerve by the pterygomandibular technique. The medial faces of 91 mandibular ramus were photographed. The exemplars presented different number of teeth, from none to 16. Measurements on the digital images were taken. The results revealed great variety on the position of mandibular foramen. They have been localized posterior and inferiorly to the middle point of the ramous on the majority of the exemplars, presenting no relation with the amount of teeth. In $95 \%$ of the sample, the reported length of short anesthetic needles seemed to be appropriated to the blockage of inferior alveolar nerve through pterygomandibular technique.

KEY WORDS: Mandibular foramen; Pterygomandibular technique; Sagittal splitting of mandible.

\section{INTRODUCTION}

The most frequent technique failure in anesthesia of the inferior alveolar lies in the inappropriate setting of the needle, due to the inaccurate location of anatomic repairs (Hetson et al., 1988), among which the mandibular foramen (MF). The risk of undesirable mandibular fractures might decrease when the MF is taken as anatomic repairs in osteotomies performed for orthognathic purposes (Quevedo Rojas, 2004).

Descriptions of MF location are generalized (Sicher \& Dubrul, 1991; Marzola, 1992; Lima, 1996) and, sometimes, researchers do not come to an agreement as to its position in the anteroposterior direction (Keros-Naglic et al., 1997) and as to the occlusal plane (Minarelli \& Ramalho, 1989; Afsar et al., 1998). There are variations arisen from craniofacial growth (Osaka, 1989; Minarelli \& Ramalho, 1989, 1991) and also from anatomic variations (Nicholson, 1985; Kaffe et al., 1994). A few studies have demonstrated that MF maintains its location after squeleton maturation, even if the mandibular ramous (MR) suffers morphological alteration associated with tooth losses (Carvalho et al., 2003; Afsar et al.).

The goal of this investigation was to identify the MF location in relation to the limits of mandibular ramous and to the quadrant of the ramous, taking horizontal and vertical directions. Also, from the data given by the literature, short anesthetic needles were analyzed as to their suitability to block the inferior alveolar nerve by the pterygomandibular technique.

\section{MATERIAL AND METHOD}

The research was approved by the Committee of Ethics of UFMS (protocol $\mathrm{n}^{\mathrm{o}} 713$; April $4^{\text {th }}, 2006$ ). Ninetynine human mandibles from the bone collection of Federal University of Mato Grosso do Sul Anatomy Laboratory have been analyzed. They were divided into three groups,

\footnotetext{
* Professor of the Morpho-Physiology Department of the Federal University of South Mato Grosso, Brazil.

**MDS, Campo Grande, MS., Brazil.
} 
according to the number of teeth: Group 1, with 17 edentulous mandibles; Group 2, with 34 mandibles ranging from 1 to 10 teeth, and Group 3, with 40 mandibles ranging from 11 to 16 teeth.

The medial face of both sides of MR was photographed with a digital camera (Sony Cybershot DSCS60 4.1Mp), placed perpendicularly at a distance of $15 \mathrm{~cm}$ from the ramous surface. A millimeter ruler was included in the image to maintain the proportion when using program Image Tol ${ }^{\circledR}$. The following distances were measured: 1) the smallest distance between the anterior border $(\mathrm{Ab})$ and the anterior limit of MF (Ab-MF distance); 2) the smallest distance between the posterior limit of MF and the posterior border (distance MF- $\mathrm{Pb}$ ); 3) the smallest distance between the inferior limit of MF and the mandibular base (MB) (MFMB distance); 4) the smallest distance between the lowest point of the mandibular incisure (MI) and the inferior limit of MF (MI-MF distance); 5) the smallest distance between $\mathrm{Ab}$ and $\mathrm{Pb}$ passing by $\mathrm{MF}$ (Ba-Bp distance) and 6) the gonial angle (Go), determined between a line that followed the tangent passing by two points of greater convexity of $\mathrm{Pb}$ and another line that followed the tangent passing by two points of greater convexity of MB (Fig. 1). In order to calculate the distance between MB and the residual alveolar ridge at mentum symphysis level (distance $\mathrm{S}$ ) in edentulous mandibles, the photograph was taken frontally.

Data were statistically analyzed using program BioEstat ${ }^{\circledR}$ 4.0. The standard deviation and the average of each distance have been calculated. The correlation between the angle Go and other distances was analyzed by the Pearson linear correlation test. In this test, the coefficient $-\mathrm{R}-$ might vary from -1 to +1 ; and the closer to these values, the stronger

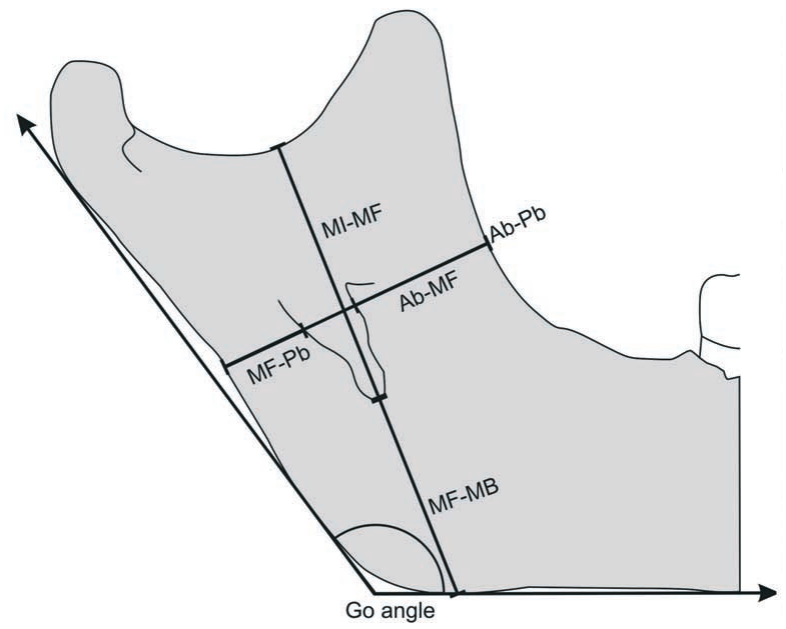

Fig. 1. Schematic representation of measurements taken in mandibles. the association of the variables. Positive scores indicate a directly proportional correlation; negative scores demonstrate an inversely proportional correlation; and zero indicates no correlation. The level of significance adopted was $95 \%$, or $\mathrm{p} \leq 0.05$.

The quadrant where MF was located, horizontally, was obtained by identifying the distance between the Ab of MR and the mean point of the MF opening hole, calculated by subtracting, from $\mathrm{Ab}-\mathrm{Pb}$, the sum of the distances $\mathrm{Ab}$ MF and MF-Pb. The result yields the width of MF. This distance was divided into halves to determine the mean point of the MF opening hole, and added to distance Ab-MF. It was then calculated, in percentage, how much the distance between $\mathrm{Ab}$ and the mean point of MF represented in relation to the total distance $(\mathrm{Ab}-\mathrm{Pb})$. This value indicated in which quadrant MF was in an anteroposterior location (Fig. 2). Values from 0 to $25 \%$ comprised the first quadrant; from $26 \%$ to $50 \%$, the second; from $51 \%$ to $75 \%$, the third; and from $76 \%$ to $100 \%$, the forth. In vertical direction, the quadrant on which MF was located was identified by calculating how much MI-MF represented, in percentage, of the addition of MI-MF and MF-MB distances (Fig. 2).

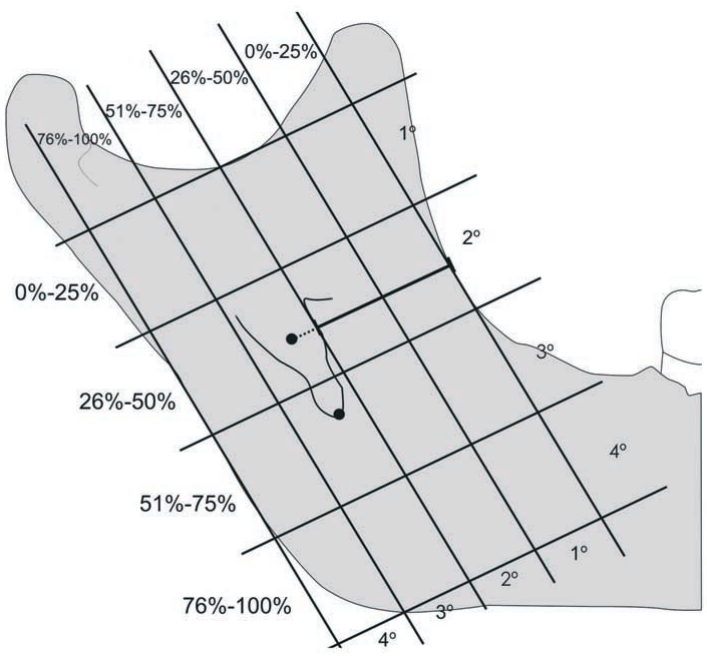

Fig. 2. Scheme of the mandibular ramous division in quadrants.

To analyze whether a short anesthetic needle would have a proper dimension to accomplish the pterygomandibular technique to block the inferior alveolar nerve, a comparison was made between the distance from $\mathrm{Ab}$ and the mean point of MF, the ideal point to infiltrate the anesthetic solution, with the length of the short anesthetic needles available in the market, described by Monteiro et al. (1999). 


\section{RESULTS}

The mean distance for each measurement of both sides of the mandible, the standard deviation and the variations of the three groups are summarized in Tables I, II and III. Correlation coefficients of mandible angle for each measurement of both sides of the three groups are shown in
Tables IV, V and VI. The distribution of the sample was shown to be normal, confirmed by the variation test coefficient calculated for each group. The quadrant on which MF was located, the average of the distance between $\mathrm{Ab}$ and the middle point of MF in the three groups, and the length of short and long anesthetic needles are presented in Tables VII, VIII and IX. A summary of the average of measurements is presented in Table X.

Table I. Media of measurements, pattern deviation, minimum and maximum values of Group 1. PD = pattern deviation

\begin{tabular}{lcccc}
\hline Measurement & side & media & $\boldsymbol{P D}$ & minimum-maximum \\
\hline \multirow{2}{*}{ Ab-MF } & $\mathrm{R}$ & 13.9 & 3.0 & $7.8-19.4$ \\
& $\mathrm{~L}$ & 14.3 & 2.8 & $9.5-21.3$ \\
MF-PB & $\mathrm{R}$ & 10.6 & 2.1 & $3.2-11.2$ \\
& $\mathrm{~L}$ & 11.1 & 1.6 & $5.8-10.7$ \\
MI-MF & $\mathrm{R}$ & 22.1 & 3.9 & $17.8-31.8$ \\
& $\mathrm{~L}$ & 21.3 & 3.8 & $16.9-29.9$ \\
MF-MB & $\mathrm{R}$ & 18.8 & 3.3 & $12.6-25.0$ \\
& $\mathrm{~L}$ & 19.4 & 3.6 & $12.4-25.8$ \\
Ab-Pb & $\mathrm{R}$ & 26.8 & 3.2 & $21.1-32.4$ \\
& $\mathrm{~L}$ & 26.1 & 4.1 & $17.8-34.9$ \\
Go angle & $\mathrm{R}$ & 131.8 & 8.5 & $122.3-156.1$ \\
$\mathrm{~S}$ & $\mathrm{~L}$ & 131.2 & 8.2 & $119.6-155.5$ \\
& & 21.7 & 5.1 & $13.0-30.0$ \\
\hline
\end{tabular}

Table II. Media of measurements, pattern deviation, minimum and maximum values of Group 2. PD = pattern deviation.

\begin{tabular}{lcccc}
\hline Measurement & side & media & $\boldsymbol{P D}$ & minimum-maximum \\
\hline \multirow{2}{*}{ Ab-MF } & $\mathrm{R}$ & 14.6 & 2.9 & $9.4-20.3$ \\
& $\mathrm{~L}$ & 14.6 & 3.2 & $6.9-20.6$ \\
$\mathrm{MF}-\mathrm{PB}$ & $\mathrm{R}$ & 12.1 & 2.3 & $8.6-18.2$ \\
& $\mathrm{~L}$ & 12.3 & 2.3 & $8.4-17.7$ \\
$\mathrm{MI}-\mathrm{MF}$ & $\mathrm{R}$ & 24.3 & 3.3 & $18.3-32.5$ \\
& $\mathrm{~L}$ & 24.4 & 3.6 & $17.5-33.7$ \\
$\mathrm{MF}-\mathrm{MB}$ & $\mathrm{R}$ & 22.3 & 4.8 & $10.5-29.5$ \\
& $\mathrm{~L}$ & 22.4 & 5.1 & $12.6-33.0$ \\
$\mathrm{Ab}-\mathrm{Pb}$ & $\mathrm{R}$ & 29.2 & 3.9 & $21.2-37.7$ \\
& $\mathrm{~L}$ & 29.4 & 4.0 & $22.6-37.5$ \\
Go angle & $\mathrm{R}$ & 125.6 & 7.8 & $106.0-145.1$ \\
& $\mathrm{~L}$ & 125.7 & 9.2 & $105.0-147.94$ \\
\hline
\end{tabular}


ENNES, J. P. \& MEDEIROS, R. M. Localization of mandibular foramen and clinical implications. Int. J. Morphol., 27(4):1305-1311, 2009

Table III. Media of measurements, pattern deviation, minimum and maximum values of Group 3. PD = pattern deviation.

\begin{tabular}{lcccc}
\hline Measurement & side & media & $\boldsymbol{P D}$ & minimum-maximum \\
\hline Ab-MF & $\mathrm{R}$ & 14.6 & 2.9 & $9.4-20.3$ \\
& $\mathrm{~L}$ & 14.6 & 3.2 & $6.9-20.6$ \\
$\mathrm{MF}-\mathrm{PB}$ & $\mathrm{R}$ & 12.1 & 2.3 & $8.6-18.2$ \\
& $\mathrm{~L}$ & 12.3 & 2.3 & $8.4-17.7$ \\
$\mathrm{MI}-\mathrm{MF}$ & $\mathrm{R}$ & 24.3 & 3.3 & $18.3-32.5$ \\
& $\mathrm{~L}$ & 24.4 & 3.6 & $17.5-33.7$ \\
$\mathrm{MF}-\mathrm{MB}$ & $\mathrm{R}$ & 22.3 & 4.8 & $10.5-29.5$ \\
& $\mathrm{~L}$ & 22.4 & 5.1 & $12.6-33.0$ \\
$\mathrm{Ab}-\mathrm{Pb}$ & $\mathrm{R}$ & 29.2 & 3.9 & $21.2-37.7$ \\
& $\mathrm{~L}$ & 29.4 & 4.0 & $22.6-37.5$ \\
Go angle & $\mathrm{R}$ & 125.6 & 7.8 & $106.0-145.1$ \\
& $\mathrm{~L}$ & 125.7 & 9.2 & $105.0-147.94$
\end{tabular}

Table IV. Correlation between linear distances and Go angle measurements in Group 1.

\begin{tabular}{|c|c|c|c|c|c|c|c|}
\hline & side & Ab-MF & MF-Pb & MI-MF & MF-MB & Ab-Pb & $\mathbf{S}$ \\
\hline \multirow[t]{2}{*}{ Go angle } & $\mathrm{R}$ & $R=-0.5858$ & $R=-0.2748$ & $R=-0.1990$ & $R=-0.6344$ & $R=-0.4668$ & $R=-0.0474$ \\
\hline & & $p=0.0134$ & $\mathrm{p}=0.2860$ & $\mathrm{p}=0.4439$ & $\mathrm{p}=0.0062$ & $\mathrm{p}=0.0588$ & $\mathrm{p}=0.8567$ \\
\hline \multirow[t]{2}{*}{ Go angle } & $\mathrm{L}$ & $R=-0.2603$ & $R=-0.1268$ & $R=-0.0182$ & $R=-0.5830$ & $R=-0.3478$ & $R=-0.0211$ \\
\hline & & $\mathrm{p}=0.3129$ & $\mathrm{p}=0.6278$ & $\mathrm{p}=0.9448$ & $\mathrm{p}=0.0140$ & $\mathrm{p}=0.1712$ & $\mathrm{p}=0.9361$ \\
\hline
\end{tabular}

Table V. Correlation between linear distances and Go angle measurements in Group 2.

\begin{tabular}{lcccccc}
\hline & side & Ab-MF & MF-Pb & MI-MF & MF-MB & Ab-Pb \\
\hline Go angle & $\mathrm{R}$ & $R=-0.4543$ & $R=-0.3353$ & $R=-0.1559$ & $R=-0.7262$ & $R=-0.5134$ \\
& & $p=0.0069$ & $\mathrm{p}=0.0525$ & $\mathrm{p}=0.3785$ & $\mathrm{p}<0.0001$ & $\mathrm{p}=0.0019$ \\
Go angle & $\mathrm{L}$ & $R=-0.4805$ & $R=-0.4353$ & $R=-0.1250$ & $R=-0.8385$ & $R=-0.6073$ \\
& & $\mathrm{p}=0.0040$ & $\mathrm{p}=0.0100$ & $\mathrm{p}=0.4811$ & $\mathrm{p}<0.0001$ & $\mathrm{p}=0.0001$ \\
\hline
\end{tabular}

Table VI. Correlation between linear distances and Go angle measurements in Group 3.

\begin{tabular}{lcccccc}
\hline & side & Ab-MF & MF-Pb & MI-MF & MF-MB & Ab-Pb \\
\hline Go angle & $\mathrm{R}$ & $R=-0.3684$ & $R=-0.4503$ & $R=-0.0546$ & $R=-0.5788$ & $R=-0.5913$ \\
& & $p=0.0193$ & $\mathrm{p}=0.0035$ & $\mathrm{p}=0.7379$ & $\mathrm{p}<0.0001$ & $\mathrm{p}<0.0001$ \\
Go angle & $\mathrm{L}$ & $R=-0.3750$ & $R=-0.4462$ & $R=-0.0269$ & $R=-0.5203$ & $R=-0.5558$ \\
& & $\mathrm{p}=0.0171$ & $\mathrm{p}=0.0039$ & $\mathrm{p}=0.8690$ & $\mathrm{p}=0.0006$ & $\mathrm{p}=0.0002$ \\
\hline
\end{tabular}

Table VII. Percentile of the distance from to MF in relation to the distance $\mathrm{Ab}-\mathrm{Pb}$, percentile of the distance MI-MF in relation to MI-MF+MF-MB and quadrant of FM localization on anteroposterior and superoinferior senses, according to Groups and sides. AP = Anteroposterior; $\mathrm{SI}=$ Superoinferior.

\begin{tabular}{lrrrrr}
\hline Group & side & AP localization & quadrant & S I localization & quadrant \\
\hline 1 & $\mathrm{R}$ & $61.60 \%$ & $3^{\circ}$ & $53.70 \%$ & $3^{\circ}$ \\
& $\mathrm{L}$ & $61.20 \%$ & $3^{\circ}$ & $52.30 \%$ & $3^{\circ}$ \\
2 & $\mathrm{R}$ & $54.10 \%$ & $3^{\circ}$ & $52.50 \%$ & $3^{\circ}$ \\
3 & $\mathrm{~L}$ & $53.60 \%$ & $3^{\circ}$ & $52.40 \%$ & $3^{\circ}$ \\
3 & $\mathrm{R}$ & $53.60 \%$ & $3^{\circ}$ & $53.60 \%$ & $3^{\circ}$ \\
& $\mathrm{L}$ & $54.20 \%$ & $3^{\circ}$ & $52.60 \%$ & $3^{\circ}$ \\
\hline
\end{tabular}


Table VIII. Measurement of media distance from Ab to medium point of MF, according to the group and side.

\begin{tabular}{lcc}
\hline Group & side & Ab-MF medium point \\
\hline 1 & $\mathrm{R}$ & 16.3 \\
& $\mathrm{~L}$ & 16.2 \\
2 & $\mathrm{R}$ & 15.9 \\
& $\mathrm{~L}$ & 15.8 \\
3 & $\mathrm{R}$ & 16.5 \\
& $\mathrm{~L}$ & 16.6 \\
\hline
\end{tabular}

Table IX. Measurement media of needle length, according to the type and fabricator. Source: Monteiro et al. (1999).

\begin{tabular}{lcc} 
Fabricator & type & length $(\mathbf{m m})$ \\
\hline B.D. & short & 22.5 \\
Gengibras & short & 19.4 \\
Monoject & short & 24.2 \\
Nipro & short & 20.0 \\
B.D. & long & 31.4 \\
Gengibras & long & 32.3 \\
Monoject & long & 35.2
\end{tabular}

Table X. Measurement media obtained from measurements taken in experimental groups.

$\begin{array}{llll}\text { Obtained measurements } & \text { G1 } & \text { G2 } & \text { G3 } \\ \text { Ab-MF distance }(\mathrm{mm}) & 14.2 & 14.6 & 15.9 \\ \mathrm{MF}-\mathrm{Pb} \text { distance }(\mathrm{mm}) & 10.8 & 12.8 & 13.4 \\ \mathrm{MI}-\mathrm{MF} \text { distance }(\mathrm{mm}) & 21.7 & 24.3 & 24.5 \\ \mathrm{MF}-\mathrm{MB} \text { distance }(\mathrm{mm}) & 19.1 & 22.3 & 21.7 \\ \mathrm{Ab}-\mathrm{Pb} \text { distance }(\mathrm{mm}) & 26.4 & 29.3 & 30.6 \\ \text { Go angle }\left({ }^{\circ}\right) & 131.5 & 125.6 & 124.1 \\ \text { Quadrant of anteroposterior localization } & \text { third } & \text { third } & \text { third } \\ \text { Quadrant of superoinferior localization } & \text { third } & \text { third } & \text { third }\end{array}$

\section{DISCUSSION}

The localization of MF presented great variation, but there was no significant variation between the right and left sides, as previously described (Hayward et al., 1977; Urbina et al., 1984; Nicholson; Minarelli \& Ramalho, 1991; Christopher et al., 1993). Mendoza et al. (2004) have found significant difference for the measurements of MI-MF and $\mathrm{MF}-\mathrm{Pb}$ on different sides.

Some anesthetic protocols proclaim the utilization of long needles in pterygomandibular technique of inferior alveolar nerve blockage (Jorgensen \& Hayde, 1967; Marzola). Long needles are, on average, $33 \mathrm{~mm}$ long; short needles, $21.5 \mathrm{~mm}$ (Monteiro et al.). The use of long needles in patients with small mandibles might induce a technical failure: there is a risk of perforating the parotid gland capsule, where the infiltration of the anesthetic solution may lead to the blockage of facial nerve ramous, provoking the temporal palsy of some mimic group muscles (Lima). On the other hand, the use of short needles in big-sized mandibles might lead to needle fracture when totally introduced in mouth tissues (Monteiro et al.; Lima).
Although it was impossible to establish absolute values to describe the position of MF, its most frequent location was in the third quadrant in both anteroposterior and superoinferior directions, in accordance with previously described results (Hayward et al.; Hetson et al.; Minarelli \& Ramalho, 1989; Hwang et al., 1990; Minarelli \& Ramalho, 1991; Oguz \& Bozkir, 2002) but different from others (Keros-Naglic et al.; Oguz \& Bozkir). There was no relation between the position of the MF and the quantity of teeth or the height of the mandible body at middle line level. The distance between $\mathrm{Ab}$ and the mean point of $\mathrm{MF}$, the ideal place for the anesthetic solution to be infiltrated, was, on average, 16.2 $\mathrm{mm}$ (calculated from the averages shown in Table VIII); only four exemplars showed a distance bigger than 21.5 $\mathrm{mm}$. The maximum value found was $25.5 \mathrm{~mm}$ and the minimum $10.3 \mathrm{~mm}$. The results allow affirming that, in more than $95 \%$ of the exemplars, the blockage of the alveolar inferior nerve would probably be accomplished with the use of short needles following the pterygomandibular technique. 
In some anesthetic techniques, molar occlusal plane helps to locate MF. Marzola observed that the introduction of the needle should be $1 \mathrm{~cm}$ above the molar occlusal plane. This maneuver is justified when the results of Hwang et al. are considered, in which MF was found even $4.2 \mathrm{~mm}$ above the occlusal plane, in adults. But not justified when confronted with the results presented by Nicholson, who found MF below the occlusal plane in $75 \%$ of the exemplars and $22 \%$ at the same level, similar to the findings of Afsar et al. In children, Marzola suggested that the syringe-needle set should be inclined in such a way to establish an angle of approximately $5^{\circ}$, in anteroposterior direction with the occlusal plane of molars. This is compliant with the results obtained by Osaka; Minarelli \& Ramalho (1991), Hwang et al., who found MF, on average, $4.1 \mathrm{~mm}$ below the occlusal plane in three-year-old children, moving towards this plane as age increased, reaching this level at the age of nine (Hwang et al.). The displacement of MF towards the occlusal plane is due to child growth and development, which implies a decrease of Go angle, and also to the presence of permanent teeth of inferior arch. These teeth presence change the orientation of occlusal plane that has a tendency to diminish its inclination in relation to MB (Minarelli \& Ramalho, 1989). In the present study, the absence of this reference in most of the exemplars restrained the measurement of the distance between MF and the occlusal plane.

The average of Go angle was $125.6^{\circ}$, with a standard deviation between 6.2 and $9.2^{\circ}$; different from that described by Nicholson: $115.4^{\circ}$, with a standard deviation of $\pm 11.0^{\circ}$. The finding of Oguz \& Bozkir was an average of $120.2^{\circ}$, with a standard deviation of \pm 4.7 . The high value of the standard deviation has demonstrated the great anatomic variation from an individual to another. It is worthwhile observing that the Go angle is related to the anteroposterior width of MR and to the distance between MF and MB in an inversely proportional relation, with negative scores and nearer to -1. This means that, in individuals with a wide Go angle, it is likely to accomplish inferior alveolar nerve blockage with a puncture lower than the conventional one with short needles. In individuals with a smaller Go angle, it is likely to accomplish inferior alveolar nerve blockage with a puncture higher than the conventional one, with lower probability of success with short needles.

To perform a saggital osteotomy on mandibles, a procedure for orthognathic purpose, a previous location of MF is necessary. The section is performed horizontally on the medial face of MR, located superior and posterior to MF, followed by a vertical descendent section that crosses $\mathrm{Ab}$ until MB, at the height of the last molar, being concluded with the fracture in order to split the fragments (Quevedo Rojas). Urbina et al. proclaim that the horizontal section should be performed $1 \mathrm{~cm}$ far from MI; whereas, according to Quevedo Rojas, this distance should be $0.5 \mathrm{~cm}$. The average distance MI-MF found by this study points to greater safety with the technique defended by Quevedo Rojas, as the distance from MI would decrease the risk of fracture reaching the condylar process (Daw et al., 1999). The extension of the osteotomy to the posterior side should be limited to the posterior wall of MF. According to the findings of this study, the mean distance between this point and $\mathrm{Ab}$ is $24.8 \mathrm{~mm}$, different from the results found by Daw et al., in which that distance was $22.1 \mathrm{~mm}$. These differences point to the need of individual evaluation; the average measurements serving just as initial parameters.

Despite the great variation of MF position, its most frequent location, in the mean third of MR both in anteroposterior and superoinferior directions, and the inversely proportional relation of the Go angle with the width and height of MR could be considered as preliminary orientation to plan clinical and surgical procedures in the pterygomandibular region.

ENNES, J. P. \& MEDEIROS, R. M. Localización del foramen mandibular e implicancias clínicas.Int. J. Morphol., 27(4):1305-1311, 2009.

RESUMEN: El foramen mandibular constituye um punto de reparo anatómico para procedimientos anestésicos y quirúrgicos. Su localización está rodeado de dificultades y divergencias. El objetivo de esta investigación fue identificar la posición del foramen en mandíbulas humanos edentadas totales, parciales y dentados. Además, a partir de datos de la literatura, investigar si la dimensión descrita de las agujas cortas son apropiadas para la ejecución de la técnica anestésica pterigomandibular. Fue fotografiada la cara medial de la rama de 91 mandíbulas con un número de dientes entre cero y dieciséis. Las mediciones fueron realizadas en las imágenes digitales. Los resultados revelaron gran variación en la posición del foramen mandibular, siendo éste localizado, en la mayoría de los ejemplares, posterior e inferiormente al punto medio de la rama mandibular, sin haberse determinado relación de posición con la cantidad de dientes. En el 95\% de la muestra, la longitud de las agujas anestésicas cortas se mostró adecuada para el bloqueo del nervio alveolar inferior por la técnica pterigo-mandibular.

PALABRAS CLAVE: Foramen mandibular; técnica pterigomandibular; División sagital de la mandíbula. 


\section{REFERENCES}

Afsar, A.; Haas, D. A.; Rossouw, P. E. \& Wood, R. E. Radiographic localization of mandibular anesthesia landmarks. Oral Surg. Oral Med. Oral Pathol. Oral Radiol. Endod., 86(2):234-41, 1998.

Carvalho, P. L.; Pocobello; M. C. \& Reis, S. S. P. Contribuiçäo ao estudo da posiçäo do forame mandibular nas radiografias panorâmicas. Arq. odontol., 39(1):45$52,2003$.

Christopher, H. M.; Avital, M. B. J.; Steven, M. W. \& Sheldon, M. M. Dimorphic study of surgical anatomic landmarks of the lateral ramus of the mandible. Oral Surg. Oral Med. Oral Pathol., 75(4):436-8, 1993.

Daw, J. L. Jr.; de la Paz, M. G.; Han, H.; Aitken, M. E. \& Patel, P. K. The mandibular foramen: an anatomic study and its relevance to the sagittal ramus osteotomy. $J$. Craniofac. Surg., 10(6):475-9, 1999.

Hayward, J.; Richardson, E. R. \& Malhotra, S. K. The mandibular foramen: Its anteroposterior position. Oral Surg. Oral Med. Oral Pathol., 44(6):837-43, 1977.

Hetson, G.; Share, J.; Frommer, J. \& Kronman, J. H. Statistical evaluation of the position of the mandibular foramen. Oral Surg. Oral Med. Oral Pathol., 65(1):324, 1988 .

Hwang, T. J.; Hsu, S. C.; Huang, Q. F. \& Guo, M. K. Age changes in location of mandibular foramen. Zhonghua Ya Yi Хие Hui Za Zhi, 9(3):98-103, 1990.

Jorgensen, N. B. \& Hayden, J. Jr. Anestesia Odontológica. $1^{a}$ edição. México D. F., Nueva Editorial Interamericana, 1967.

Kaffe, I.; Ardekian, L.; Gelerenter, I. \& Taicher, S. Location of the mandibular foramen in panoramic radiographs. Oral Surg. Oral Med. Oral Pathol., 78(5):662-9, 1994.

Keros-Naglic, J.; Panduric, J. \& Buntak-Kobler, D. Some anatomical and anthopological measures of mandibular ramus in our population. Coll. Antropol., 21(1):203-10, 1997.

Lima, J. R. S. Atlas colorido de Anestesia Local em Odontologia - Fundamenteos e Técnicas. $1^{\mathrm{a}}$ ed. São Paulo, Santos Editora, 1996.
Marzola, C. Anestesiologia. $2^{\text {a }}$ ed. São Paulo, Panamed, 1992.

Mendoza, C. C.; Vasconcelos, B. C. E.; Sampaio, G.; Cauás, M. \& Batista, J. E. M. Localização topográfica do forame mandibular: estudo comparativo em mandíbulas humanas secas. Rev. Cirurg. Traumat. Buco-maxilo-facial, 4(2):137-42, 2004.

Minarelli, A. M. \& Ramalho, L. R. T. Posição do forame da mandíbula em função do crescimento. Estudo antropométrico em radiografia de crianças. Rev. Bras. Ciên. Morfol., 6(2):100-7, 1989.

Minarelli, A. M. \& Ramalho, L. R. T. Estudo da localização do forame da mandíbula através de mandíbulas maceradas de crianças. Rev. Odont. UNESP, 20:119-27, 1991.

Monteiro, L. P.; Toschi, S. R. T.; Nosé, A. R. \& Kuramochi, M. M. Comprimento da agulha em relação à técnica ptérigo-mandibular. Rev. Inst. Ciênc. Saúde, 17(2):935, 1999.

Nicholson, M. L. A study of the mandibular foramen in the adult human mandible. Anat. Rec., 212(1):110-2, 1985.

Oguz, O. \& Bozkir, M. G. Evaluation of the location of the mandibular and mental foramina in dry, young, adult human male, dentulous mandibles. West Indian Med. J., 51(1):14, 2002.

Osaka, N. Studies on the position of the mandibular foramen. Shoi shikagaku Zasshi, 27(1):9-20, 1989.

Quevedo Rojas, L. A. Osteotomía sagital de rama mandibular en cirugía ortognática. Rev. Esp. Cirug. Oral y Maxilofac., 26(1):14-21, 2004.

Sicher, H. \& Dubrul, E. L. Anatomia Oral de Sicher e DuBrull. 8. Ed. São Paulo, Artes Médicas, 1991.

Urbina, H. O.; Marcos, G. E. \& Nydia, E. A. M. Medidas anatomicas de la mandibula aplicadas a la tecnica de Obwegeser-Dal Pont. An. Anat. Norm., 2(2):34-6, 1984.

\author{
Correspondence to: \\ Jussara Peixoto Ennes \\ Professor of the Morpho-Physiology Department \\ Federal University of South Mato Grosso \\ BRASIL
}

Received: 17-09-2008

Accepted: 25-11-2009 
